\title{
Age of a Victim as Crime's Feature in Roman LaW ${ }^{* *}$
}

\section{Introduction}

Writing about responsibility for unlawful acts in relation to age, the subject of perpetrator and the ability to bear such liability arises first of all. In Roman law unlawful acts were divided into private ones (delicta) and public ones (crimina). ${ }^{1}$ Delicts were perceived as infringement of interests (usually in terms of private and personal property) and those cases were dealt with civil proceedings, while crime was deemed to be dangerous to the order of the state and was recognised in the course of the criminal trial. Especially in the initial period, the principles of the perpetrator's liability for delicts and crime were similar to one another. From

* Ph.D., LL.M., Assistant Professor, University of Rzeszów; e-mail: wjkosior@ur.edu.pl, ORCID ID: https://orcid.org/0000-0002-4710-4523.

* Special thanks are due to the Polish Academy of Learning for granting me the Scholarship of De Brzezie Lanckoroński Foundation, which helped me to conduct my scientific research on this subject.

1 On the distinction between delicts and crimes cf. C. Cascione, Roman Delicts and Criminal Law: Theory and Practice, in: Obligations in Roman Law: Past, Present, and Future, ed. Th.A.J. McGinn, Ann Arbor 2012, pp. 267-296; G. Longo, Delictum e crimen, Milano 1976, p. 180; E. Albertario, Delictum e crimen nel diritto romano-classico e nella legislazione giustinianea, Milano 1924, p. 74; F. Lucrezi, G. Mancini, Crimina e delicta nel tardo antico. Atti del Seminario di Studi. Teramo, 19-20 gennaio 2001, Milano 2003, pp. 17 ff. Cf. K. Amielańczyk, Vis - pomiędzy prawem rzymskich deliktów prywatnych a rzymskim prawem karnym publicznym, in: Przemoc w świecie starożytnym: źródła, struktura, interpretacje, ed. D. Słapek, I. Łuć, Lublin 2017, pp. 283-298. Recently on the example of the history of German law cf. P. Hellwege, P. Wittig, Delictual and Criminal Liability in Germany, in: Comparing Tort and Crime: Learning from across and within Legal Systems, ed. M. Dyson, Cambridge 2015, pp. 123-172. 
the point of view of both, delictual and criminal responsibility and age, three consecutive categories were important: children (infantes), immature (impuberes) and mature (puberes). As a rule, the children did not take any responsibility, the immature bore the responsibility on the condition that they were able to recognise the meaning of the committed act, and the mature were fully and unconditionally responsible for their acts. ${ }^{2}$

In the Roman law sources the matter of age appeared several times in the liability context in which the age of a victim was a feature of selected delicts and types of crime. That demonstrates that in Roman law, in cases of unlawful acts, not only the perpetrator's age was important in terms of legal responsibility, but also sometimes the perpetrator's liability depended on the age of the victim. Modern law contains the provisions in which the perpetrator's liability depends on the age of a victim. For example, criminal offences committed to the detriment of minors (e.g. Article 200 $\S 1$ of the Polish Penal Code $^{3}$ ) may be mentioned here. In other words, there are certain types of crime which may be committed only if a victim is a person of an exact age.

In my research I would like to verify how the perpetrator's liability was dependent on the age of a victim. The selected Roman law sources provided for the analysis and description of unlawful acts (mostly criminal offences) occurring in Roman law, in which the perpetrator's liability was strictly intertwined with a victim's age. The key matter of this research is to investigate and determine the role of age in the above context by presenting selected age categories which appeared in the sources. So far, the above-mentioned theme hasn't been described in the related literature because - when the matter of age in the criminal liability context was analysed - the most attention was focused on the age of the perpetrator and his ability to bear liability for unlawful acts. More specifically, in

2 Cf. W.J. Kosior, Kategorie i granice wieku oraz ich znaczenie w prawie rzymskim, Warszawa 2018 (unpublished doctoral thesis, archive of Uniwersytet Humanistycznospołeczny SWPS w Warszawie), pp. 388-418.

3 Art. $200 \S 1$ of the Penal Code: “Kto obcuje płciowo z małoletnim poniżej lat 15 lub dopuszcza się wobec takiej osoby innej czynności seksualnej lub doprowadza ją do poddania się takim czynnościom albo do ich wykonania, podlega karze pozbawienia wolności od lat 2 do 12." [Art. $200 \S 1$ : "Anyone who has sexual intercourse with a minor under the age of 15, or commits any other sexual act, or leads him or her to undergo such an act or to execute such an act, is liable to imprisonment from 2 to 12 years"], the uniform text: Dziennik Ustaw [Journal of Laws] from 2019 item 950 as amended. 
previous studies the key problem was the examination of the relation between the perpetrator's age and the liability for both, delicts and criminal offences. Most efforts were put into finding answers to questions about the perpetrator's appropriate age to hold criminal responsibility. This research goal is different because the effort is put on the analysis of a victim's age and its role in determining the perpetrator's criminal responsibility. Therefore, this paper first presents the Roman concept of crime and its features. Secondly, it deals with the age feature and its role in the crime concept described in ancient sources. Then, it focuses on the texts which deal with the perpetrator's criminal liability and mention the connection between the liability and a victim's age.

\section{Crime and Its Features}

In ancient Rome any person involved in crime, whether as accused or as a witness might be differently treated depending on sex, age, social status, legal status, and state of mind, as well as the time, place and nature of crime. ${ }^{4}$ The Romans did not develop the science of criminal offence, yet they attempted to describe the nature and characteristic features of public law crime. According to the Justinian Digest, the jurist who made such an attempt was Claudius Saturninus. He distinguished between criminal offences based mainly on the manner of committing an offence (as we call it today modus operandi). Claudius Saturninus enumerated seven elements (features) of the objective aspect of crime. The jurist illustrated all manners and circumstances of committing a criminal offence with examples. ${ }^{5}$ We know very little about Claudius Saturninus. He was a mysterious figure whose name and career are not well attested. It seems most likely that he is to be equated with the Claudius Saturninus active under the reign of Hadrian and Antoninus Pius. ${ }^{6}$

4 O.F. Robinson, The Criminal Law of Ancient Rome, Baltimore 1995, p. 15.

5 K. Amielańczyk, Teoretyczny model przestępstwa prawa publicznego (crimen publicum) autorstwa Claudiusa Saturninusa (D. 48,19,16) a wspótczesna nauka o przestępstwie karnym, Annales Universitatis Mariae Curie-Skłodowska. Sectio G. Ius 2019, vol. 66, no. 1, pp. 32-33.

6 M. Barden Dowling, Clemency \& Cruelty in the Roman World, Ann Arbor 2006, p. 331, footnote 13 . 
Claudius Saturninus wrote about the features of crime in Roman law in his work titled De poenis paganorum. It should be mentioned that the Roman interests in the theory of criminal law started for good in the imperial period. First works on this subject (De iudiciis publicis) were wrote mainly by Maecianus, Marcianus, Macer and Venuleius Saturninus. Apart from them other works were written like De officio proconsulis by Ulpian, De cognitionibus by Callistratus. Treaties devoted to the nature of crime include: De poenis omnium legum and De poenis paganorum by Paulus; De poenis by Modestinus; and De poenis paganorum by Claudius Saturninus. Most of those works were commentaries dedicated to law practitioners and imperial officials. ${ }^{7}$

From the perspective of this research the most important is the Roman concept of a public law offence model offered by Claudius Saturninus. ${ }^{8} \mathrm{He}$ described the structure of crime in Roman law. ${ }^{9}$ It is possible to follow this theory by reading the passage below:

D. 48,19,16,1 (Claudius Saturninus libro singulari de poenis paganorum): [...] Sed haec quattuor genera consideranda sunt septem modis: causa persona loco tempore qualitate quantitate eventu. [...].

From the cited opinion the crime in Roman law is found to consist of seven basic elements. Those elements known as features of crime were as follows: (1) causa, (2) persona, (3) locus, (4) tempus, (5) qualitas, (6) quantitas, and (7) eventus. Those features are understood as: the motive, the person's feature, the place and time of committing an offence, the burden of crime understood as the degree of its harmfulness, the amount perceived as damage caused by crime and the so-called result of crime. The listed elements practically determined the crime. ${ }^{10}$ From the point of view of

7 A. Chmiel, Dzieła naukowe jurystów rzymskich w zakresie prawa karnego, Studia Iuridica Lublinensia 2016, vol. 25, no. 3, p. 164.

8 K. Amielańczyk, Rzymskie prawo karne w reskryptach cesarza Hadriana, Lublin 2006, pp. $88 \mathrm{ff}$.

9 Cf. R. Bonini, D. 48,19,16 (Claudius Saturninus "de poenis paganorum"), Rivista Italiana per le Scienze Giuridiche 1959-1962, series 3, vol. 10, pp. 119 ff.; W. Mossakowski, Czyn karalny wedtug koncepcji Klaudiusza Saturnina, Acta Universitatis Wratislaviensis. Prawo 2008, no. 305. Studia Historycznoprawne. Tom poświęcony pamięci Profesora Edwarda Szymoszka, pp. 217 ff.

10 Cf. W.J. Kosior, D. 48, 2, 3 i art. 332 k.p.k. - uwagi prawnoporównawcze, Zeszyty Naukowe Uniwersytetu Rzeszowskiego. Seria Prawnicza. Prawo 2018, vol. 22, pp. 57 ff. 
the conducted research, the person's feature seems to be the most important. The development of the persona concept was explained by Claudius Saturninus in the following text:

D. 48,19,16,3 (Claudius Saturninus libro singulari de poenis paganorum): Persona dupliciter spectatur, eius qui fecit et eius qui passus est: aliter enim puniuntur ex isdem facinoribus servi quam liberi, et aliter, qui quid in dominum parentemve ausus est quam qui in extraneum, in magistratum vel in privatum. In eius rei consideratione aetatis quoque ratio habeatur.

In the above description of the feature referred to as persona, it was pointed out that in assessing the crime and its features it was also necessary to take into account the age of the person. Therefore, it was stressed out that the age in Roman penal law was one of several elements that determined the structure of crime. Krzysztof Amielańczyk ${ }^{11}$ said that, on the one hand, that reference had concerned the perpetrator and, on the other, a victim. In a reference to the perpetrator, it was most likely to determine whether a particular person could have borne any responsibility at all. As well as whether his or her age was an important factor in the subsequent assessment of the degree of culpability and punishment. A victim's age might also belong to the features of crime, which was crucial in determining the perpetrator's liability.

\section{A Victim's Age as Crime's Feature}

An in-depth analysis of the sources revealed several cases where a victim's age played a fundamental role in the existence of crime. More precisely, there were cases where the perpetrator's criminal liability depended on the age of a victim. Here is the presentation and analysis of the relevant sources. This elaboration and presentation of texts is based on the age and starts from the youngest age category.

In the post-classical law, more precisely in the constitution of the emperors Valentinian, Valens and Gratian from the year 374, death penalty was provided for killing a person in his childhood:

11 K. Amielańczyk, Rzymskie prawo karne..., p. 92. 
C. Th. 9,14,1 (Imppp. Valentinianus, Valens et Gratianus aaa. ad Probum pf. p.): Si quis necandi infantis piaculum aggressus aggressave sit, erit capitale istud malum.

C. Th. 9,14,1 (Interpr.): Sive vir sive mulier infantem necaverit, rei homicidii teneantur.

The above-mentioned act was issued in connection with the earlier Cornelia de sicariis law, adopted during the reign of Sulla (81 B.C.), which was aimed against assassins, carvers, poisoners, arsonists and murderers. ${ }^{12}$ In that case, the scope of penalisation was extended to the ritual murder of a child which was sacrificed, as indicated by the return of the necandi infantis piaculum. ${ }^{13}$ Undoubtedly, this concerned a child (a person in his childhood), not a child understood as a descendant (not its own child). As it is read in other sources, in the case of penalising the behaviour of killing own child in the sense of the descendant, the texts used the term filius to describe a son and filia to describe a daughter. ${ }^{14}$ The sanctions which were prescribed in the above-mentioned Sulla's act of law were also applicable to the people who committed human sacrifices in the later imperial times. We know it from Modestinus's opinion. ${ }^{15}$

The analysis of the sources also revealed cases of acts, unlawful nature of which was determined by the juvenile age of a victim. That included offensive and defamatory behaviour, but also sexual offence known as stuprum. That category of people who were especially protected from such acts comprised very young boys and girls who wore a toga symbolising the age of innocence, which preceded the achievement of physical maturity. Given the name of this toga - toga praetexta - it was assumed to refer to

12 Cf. K. Amielańczyk, Lex Cornelia de sicariis et veneficis: Ustawa Korneliusza Sulli przeciwko nożownikom i trucicielom 81 r. p.n.e., Lublin 2011, p. 222.

13 O.F. Robinson, The Criminal Law..., p. 44.

14 Cf. D. 48,9,1 (Marcianus libro 14 institutionum): Lege Pompeia de parricidiis cavetur, ut, si quis patrem matrem, avum aviam, fratrem sororem patruelem matruelem, patruum avunculum amitam, consobrinum consobrinam, uxorem virum generum socrum, vitricum, privignum privignam, patronum patronam occiderit cuiusve dolo malo id factum erit, ut poena ea teneatur quae est legis Corneliae de sicariis. Sed et mater, quae filium filiamve occiderit, eius legis poena adficitur, et avus, qui nepotem occiderit: et praeterea qui emit venenum ut patri daret, quamvis non potuerit dare.

15 D. 48,8,13 (Modestinus libro 12 pandectarum): Ex senatus consulto eius legis poena damnari iubetur, qui mala sacrificia fecerit habuerit. 
persons entitled to wear it, in the case of boys - praetextati and in the case of girls ${ }^{16}$ - praetextatae.

Both, in the classical and Justinian law, the delict of insult (iniuria) was the act in which the age of a victim impacted an offender's liability. The classical point of view is presented by Gaius, the $2^{\text {nd }}$ century jurist's opinion:

G. 3,220: Iniuria autem committitur non solum, cum quis pugno puta aut fuste percussus uel etiam uerberatus erit, sed etiam si cui conuicium factum fuerit, siue quis bona alicuius quasi debitoris sciens eum nihil sibi debere proscripserit siue quis ad infamiam alicuius libellum aut carmen scripserit siue quis matrem familias aut praetextatum adsectatus fuerit et denique aliis pluribus modis.

Before the above passage is explained, the cited opinion of Gaius, that was later used by Justinian and was included in Justinian Institutions, should be mentioned in the following context:

I. 4,4,1: [...] sive quis matrem familias aut Praetextatum Praetextatamve adsectatus fuerit, sive cuius pudicitia attemptata esse dicetur: et denique aliis pluribus modis admitti iniuriam manifestum est.

Those two texts, one classical and one from Justinian law, were very similar to one another. The notable difference is that Gaius wrote only about boys who were victims and in Justinian Institutions girls were also taken under legal protection. Apart from that difference, the following was considered insult: punching or beating with a stick, public reproof, public auction of a debtor's property with the knowledge that the person

16 Praetextata aetas - this age category includes people who were not yet authorized to wear a toga virilis, i.e. a gown which symbolized the adulthood. The sources do not define the exact age of these people. It is assumed that the change of the toga took place at the age between 14 and 17 or 18 years. Hence, the term praetextata aetas might be referred to persons of this age. In general, the term praetextata aetas can be defined as the age of innocence. The terms puero praetextato and praetextatus were also used to describe boys at this age, while girls used the term praetextata. Due to the legal protection of people wearing a toga praetexta against unwanted sexual behaviors, the age of these people can be described as the age of sexual innocence, cf. W.J. Kosior, Kategorie i granice wieku..., pp. 159-163; J.L. Sebesta, Symbolism in the Costume of the Roman Woman, in: The World of Roman Costume, ed. J.L. Sebesta, L. Bonfante, Madison 2001, p. 47; J.G. Cabanero, Urbs Roma: Vida y costumbres de los romanos, vol. 1. Vida privada, Salamanca 1988, p. 275; F. Dolansky, Togam virilem sumere: Coming of Age in the Roman World, in: Roman Dress and the Fabrics of Roman Culture, ed. J. Edmondson, A. Keith, Toronto-Buffalo-London 2008, pp. 47-71. 
is not a real debtor, writing a lampoon or a poem for defamation. Eventually, intrusive following (tracking) a matron or a young man (Gaius) and a young girl (Justinian) ${ }^{17}$ was also comprehended as an insult. Persons harmed by insults were described in the above texts using the terms praetextati in the case of boys, and praetextatae in the case of girls. That was a clear reference to the outfit worn by them - more specifically their age, which entitled them to wear it. As M. Kuryłowicz ${ }^{18}$ pointed out, the intrusion of someone and accompanying someone against one's will was the basis for claims for insult. This phenomenon must have been common since Gaius mentioned the most important and most frequent examples of insults. The situation when a person forbade another one to be accompanied by other people was also comprehended as an insult. ${ }^{19}$ Accompanying someone while walking was obviously normal, if it was accepted by a person. Sometimes such behaviour was intensified by verbal assaults that impacted the modesty and dignity of a person. That kind of insulting behaviour was legally described by Ulpianus as an action which harassed the morality and that was not accepted by the general customs. ${ }^{20}$

The age of people wearing the praetexta toga was also important for the perpetrator's liability for defamatory acts. Dobromiła Nowicka, ${ }^{21}$ in her work, dealt with those acts in Roman law more widely. At this point, it is absolutely necessary to point out that in Roman law, according to M. Kuryłowicz, ${ }^{22}$ defamation did not occur as a separate legal institution and, essentially, the problem of defamatory acts was generally related to a Roman insult (iniuria).

Given the area of interest, the focus should be put on the selected excerpts from Ulpianus's commentary to the edict (D. 47,10,15). Those

17 Cf. M. Kuryłowicz, Prawo i obyczaje w starożytnym Rzymie, Lublin 1994, pp. 160-161; R. Wittmann, Die Entwicklungslinien der klassischen Injurienklage, Zeitschrift der Savigny-Stiftung fur Rechtsgeschichte 1974, vol. 91, p. 329; E. Pólay, Iniuria Types in Roman Law, Budapest 1986, p. 148.

18 Cf. M. Kuryłowicz, Prawo i obyczaje..., p. 163.

19 Cf. Coll. 2,5,1,4: Fit autem iniuria vel in corpore, dum caedimur, vel verbis, dum convicium patimur, vel cum dignitas laeditur, ut cum matronae vel praetextatae comites abducuntur.

20 D. 47,10,15,20 (Ulpianus libro 77 ad edictum): Appellare est blanda oratione alterius pudicitiam adtemptare: hoc enim non est convicium, sed adversus bonos mores adtemptare.

${ }^{21}$ Cf. D. Nowicka, Zniestawienie w prawie rzymskim, Wrocław 2013, p. 337.

22 M. Kuryłowicz, Dobromiła Nowicka, Zniestawienie w prawie rzymskim, Wrocław 2013, (Uniwersytet Wroctawski, Prawnicza i Ekonomiczna Biblioteka Cyfrowa, ss. 334) [review], Zeszyty Prawnicze [UKSW] 2014, vol. 14, no. 4, p. 229. 
fragments were related to the use of edictum de adtemptata pudicitia, so the pretorian edict that protected an individual from defamatory acts, such as attacks on person's physical invulnerability and verbal, direct attacks on person's dignity or reputation, as well as other behaviour. ${ }^{23}$ Apart from the Digest, there is no direct information about the fact that the liability of the perpetrator was determined by wearing a praetexta by victims. However, such information may be found in the fragment of the pretorian edict reconstructed by O. Lenel ${ }^{24}$ (§ 192) Si quis matrifamilias aut praetextato praetextataeue comitem abduxisse siue quis eum eamue aduersus bonos mores appellasse adsectatusue esse dicetur. The quoted fragment displays that the edictum de adtemptata pudicitia protected women described as materfamilias, virgines and freeborn girls and boys entitled to wear toga praetexta. ${ }^{25}$ While analysing those texts devoted to the regulation of the edict, S. Fus$\mathrm{CO}^{26}$ expressed the view that the liability of the perpetrator of illegal acts was determined by a victim's outfit. The author personally believes that as a result of further interpretation it is plausible to state that the above-mentioned liability was determined by the age of victims (especially men) because the type of a toga they wore depended on their age. In the case of women, the exchange of a toga took place at the time of the transition from the bride to the married woman. ${ }^{27}$

The importance of the toga praetexta worn by a victim, and thus the age, was also crucial for the liability of the perpetrator in the case of a sexual offence referred to as stuprum, confirmed by the passage included in the Pauli sententiae, which is the $3^{\text {rd }}$ century compilation of selected opinions which have been attributed to Paulus: ${ }^{28}$

23 D. Nowicka, Niewerbalne sposoby naruszenia czci w prawie rzymskim, Zeszyty Prawnicze [UKSW] 2016, vol. 16, no. 1, pp. 5-7.

24 O. Lenel, Das Edictum Perpetuum, Leipzig 1927, p. 400 (§ 192).

25 D. Nowicka, Zniestawienie..., p. 67, footnote 231.

26 S. Fusco, Edictum de adtemptata pudicitia [online], Diritto@Storia. Rivista Internazionale di Scienze Giuridiche e Tradizione Romana 2010, no. 9, http:/ / www.dirittoestoria. it /9/ Tradizione-Romana / Fusco - Edictum - adtemptata- pudicitia.htm \#_ftn 80 [access: 13.06.2019]. It was also pointed out by D. Nowicka, cf. eadem, Stroje Rzymianek w kontekście brzmienia fragmentu D. 47, 10, 15, 15 (Ulpianus libro 77 ad edictum), Acta Universitatis Wratislaviensis. Prawo 2017, no. 324. Studia Historycznoprawne, p. 50, footnote 1 in fine.

27 Cf. W.J. Kosior, Kategorie i granice wieku..., p. 161.

28 Oxford Classical Dictionary, ed. S. Hornblower, A. Spawforth, Oxford-New York 2003, pp. 785-786. 
Paul. Sent. 5,4,14: Qui puero praetextato stuprum aliudve flagitium abducto ab eo vel corrupto comite persuaserit, mulierem puellamve interpellaverit, quidve pudicitiae corrumpendae gratia fecerit, donum praebuerit pretiumve, quo id persuadeat, dederit, perfecto flagitio capite punitur, imperfecto in insulam deportatur: corrupti comites summo supplicio adficiuntur.

The above fragment of the text relates to criminal responsibility for the crime, which was committed to the detriment of puero praetextato, in other words a boy wearing a toga praetexta. In this case, the toga worn by the boy symbolised his innocence in a physical sense. ${ }^{29}$ The reference to the outfit was limited only to the description of a boy dressed up in the toga praetexta. It should be recognised that the late classical law protected all women, girls and boys against whom unlawful actions were directed. In the author's opinion, the mere replacement of those terms with others did not mean that they were irreversibly out of use because in Justinian law, the terms mater familias and praetextata were used again (I. 4,4,1) to describe the tort for insults.

Conducting the research on the source material to reveal the importance of a victim's age as a feature of crime brought information about the case of an immature girl who was the victim of sexual crime. The first example of the case of an immature girl was discovered in the Digests and the second one in the opinion attributed to Paulus:

D. 47,10,25 (Ulpianus libro 18 ad edictum): Si stuprum serva passa sit, iniuriarum actio dabitur: aut, si celavit mancipium vel quid aliud furandi animo fecit, etiam furti: vel, si virginem immaturam stupraverit, etiam legis Aquiliae actionem competere quidam putant.

The first words of Ulpianus's commentaryrefer to the consequences of committing a criminal offence known as stuprum ${ }^{30}$ on a slave girl. ${ }^{31} \mathrm{In}$ such a case, the perpetrator was liable on the basis of the action called as

29 It was to emphasize his sexual incapacity, cf. Ch. Laes, J. Strubbe, Youth in the Roman Empire. The Young and the Restless Years?, Cambridge 2014, p. 57.

30 Stuprum - Illicit intercourse with an unmarried woman or a widow of honourable social conditions. Stuprum is distinguished from adultery (adulterium), cf. A. Berger, Encyclopedic Dictionary of Roman Law, Philadelphia 1953, p. 719, s.v. stuprum. See also: A. Sokala, Crimen lenocinii: Proces typizacji przestępstwa w prawie rzymskim, Toruńskie Studia Polsko-Włoskie 1994, no. 3, pp. 27-44.

31 O.F. Robinson, The Criminal Law..., p. 50. 
actio iniuriarum, or as pointed out by M.J. Perry, ${ }^{32}$ on the basis of actio servi corrupti. ${ }^{33}$ Further, as Ulpianus explained, in the case when the perpetrator committed that act on an immature slave girl who was still a virgin, the perpetrator was liable on the basis of the Aquilian complaint governed by the lex Aquilia. In this case the responsibility of the perpetrator, and more precisely the legal measures that could have been applied, were dependent on the age of the girl who was the victim of the offence. In the case of a stuprum committed on mature slave girls, the owner was entitled to use actio iniuriarum or actio servi corrupti, but when the victim was an immature slave (immatura) then it was possible to bring the actio legis Aquiliae. It should also be noted that the term immatura defined girls below the age of maturity i.e. below 12 years of age. ${ }^{34}$ In the cited opinion Ulpianus did not explain the reason why the girl's age was a distinction between legal measurements which could be used when stuprum was committed against such a girl. From the perspective of the research in the above context the key matter is that the age of a victim was a factor which determined the kind of responsibility which was taken by the perpetrator.

Similar conclusions could be drawn after the analysis of the following passage, which stated that the Aquilian complaint was also used when an unlawful act was committed on an immature slave girl.

Paul. Sent. 1,13a,6: Qui ancillam alienam virginem immaturam corruperit, poena legis aquiliae tenebitur.

At this point, it should be added that in the case described above the perpetrator did not bear typical criminal liability as for the stuprum committed on a free woman. Such behaviour was penalised by lex Iulia de adulteriis coërcendis, which made the perpetrator liability dependent on the status of a woman. ${ }^{35}$ This act did not apply to people who were deprived of liberty. Therefore, a man who had sexual relations with a slave girl did not commit a crime, hence he was not a subject to the criminal

32 M.J. Perry, Gender, Manumission, and the Roman Freedwoman, Cambridge 2014, p. 25.

33 Cf. A.A. Schiller, Trade Secrets and the Roman Law: The Actio Servi Corrupti, Columbia Law Review 1930, vol. 30, no. 6, pp. 837 ff.

${ }_{34}$ Cf. W.J. Kosior, Kategorie i granice wieku..., pp. 133-135.

35 Cf. D. $48,5,6,1$. 
sanctions provided for adultery. ${ }^{36}$ The slave owner was only entitled to use the aforementioned private law complaints.

Another case when the immature age of a victim determined whether the unlawful act was committed or not, was the offence of violating girl's virginity until she reached physical maturity. That was confirmed by the imperial constitution from 326:

C. Th. 9,8,1 (Imp. Constantinus a. ad Bassum vicarium Italiae): Post alia: ubi puellae ad annos adultae aetatis accesserint et adspirare ad nuptias coeperint, tutores necesse habeant comprobare, quod puellae sit intemerata virginitas, cuius coniunctio postulatur. Quod ne latius porrigatur, hic solus debet tutorem nexus adstringere, ut se ipsum probet ab iniuria laesi pudoris immunem. Quod ubi constiterit, omni metu liber optata coniunctione frui debebit; officio servaturo, ut, si violatae castitatis apud ipsum facinus haereat, deportatione plectatur, atque universae eius facultates fisci viribus vindicentur, quamvis eam poenam debuerit sustinere, quam raptori leges imponunt. ${ }^{37}$

The content of the imperial constitution indicates that the girl's virginity had been protected until she reached adulthood. The term adulta aetas meant formal maturity and in the case of women, it described girls above 12 years of age. Thus, in the quoted constitution, the girl's virginity had been protected by law until she reached 12 years of age. The person responsible for the protection was the girl's guardian. In the above-mentioned act the guardian's liability regarding behaviour consisting in violating the virginity of his ward was foreseen. As it is indicated in the cited passage the basic punishment for such behaviour was to expel the guardian and the forfeiture of all the property to the state treasury. In the last sentence of the constitution, it was indicated that a guardian should be punished with a qualified punishment, as in the case of rape. ${ }^{38}$ The analy-

36 D. Stolarek, Ustawa julijska o karaniu za cudzołóstwa - 5 tytut 48 księgi Digestów. Tekst ttumaczenie - komentarz, Zeszyty Prawnicze [UKSW] 2014, vol. 14, no. 4, p. 220. See also: D. Stolarek, Adultera w świetle Lex Iulia de adulteriis coërcendis, Lublin 2012, p. 229.

37 Cf. C. Th. 9,8,1 (Interpr.): Ubi primum puellae sub tutore viventes ad annos pervenerint nuptiales, et quicumque* petitor accesserit, non prius puella iungatur, nisi virginitas illius, quod a tutore servata sit, fuerit approbata: nam si ab ipso tutore convincitur eius violata virginitas, statim exsilio deputetur, et res illius omnes fiscus usurpet.

38 Cf. C. Th. 9,24,1. 
sis of the quoted text was done by J. Wiewiorowski, ${ }^{39}$ who explained that the term puellae ad annos adultae aetatis should refer to girls reaching "efficient" years, which emphasised their physical ability to accept a man. That should be understood as an equivalent to the term viripotens. The researcher also recognised that the term defined girls up to the age of 12 years old.

The age of a girl who was under the custody could also be taken as a feature of crime of adultery:

D. 48,5,7 (Marcianus libro decimo institutionum): Qui pupillam suam duxit uxorem contra senatus consultum, nec matrimonium est hoc et potest adulterii accusari, qui tutor vel curator fuit et intra vicensimum sextum annum duxit uxorem non a patre desponsam vel destinatam vel testamento denominatam.

In the above text, it was indicated that the guardian or curator bore criminal liability under the Iulia de adulteriis coërcendis act. According to this statute they took responsibility if they married with their ward before she reached the age of 26 years and was not formally assigned as the wife. Committing that act resulted in the nullity of the relationship, the illegitimate origin of the children. The guardian (or curator) who committed adulterium was sentenced to infamy and was unable to inherit from the ward and to receive donations from her. This prohibition was a consequence of the duty of the guardian (and curator), who after the expiration of the guardian or curator functions, should present bills from the administering the ward's property. The ban on marrying the ward before the expiration of custody was implemented to protect the girl from the uncontrolled depletion of her property by the guardian (or curator). ${ }^{40}$ There was a risk that a guardian or curator through marriage with a ward would like to exclude accusations of unreliable management of the girl's property. In the case described above, the age of a woman (until she completed 25 years of age and entered into 26 years) was a feature of an offence. Therefore, getting married to a former ward after she had reached the described age did not result in criminal responsibility of the former guardian or curator.

In connection with the functions of guardians and curators, it should also be noted that they were responsible for the manner of exercising their

39 J. Wiewiorowski, Regulacja przeciwko naruszeniu praw dziewczyny przez jej opiekuna - obrona wolności wyboru męża czy odrębny typ zbrodni?, U Schyłku Starożytności - Studia Źródłoznawcze 2016, no. 15, p. 14.

40 J. Misztal-Konecka, Bigamia w prawie rzymskim, Lublin 2011, p. 89. 
functions. In such cases, that responsibility (under private law) was naturally related to the age of a victim (the harmed party). Guardians and curators were responsible for acts committed during the custody that is, until the wards reached 12 (women) and 14 (men), and then up to 25 years of age, that is until the end of guardianship.

\section{Conclusion}

When the subject of criminal or delictual responsibility is undertaken, the matter of age always appears in this context. The age is significant to assume whether the perpetrator can take responsibility for own acts. Generally, the age is the factor which is used for determining if the perpetrator was aware of the legal consequences of unlawful activity. Apart from that, there are cases when age could be comprehended in a different way - as a crime's feature. Good examples of such an understanding in the modern penal codes are sexually-based offences related to legally underage victims.

In the framework of the research, which is presented in this article, the focus is put on examination of the Roman law crime which could be committed only if a victim was of a certain age. Recent studies did not deal with such a topic. If the matter of age was elaborated in the Roman penal law, it was strictly connected with the perpetrator's age and related ability to take responsibility for unlawful acts. The main issue of the previous studies was to determine if and how the perpetrator's responsibility depended on the victim's age. Thus, it has been decided to describe and analyse the Roman law sources which dealt with such a topic. As the consequence of that analysis it has been discovered that in Roman law the victim's age played a significant role in determining the perpetrator's criminal responsibility in four cases. The first case appeared in the crime of ritual killing of persons in childhood. Special punishment was prescribed for such cases. If such ritual crime was committed against an older person, the responsibility was taken as in the case of a regular murder. The second case was the case of committing an insult (iniuria) against young girls and boys. In the third case the victim's age under 12 years was very important to determine the responsibility for sexual assault of a slave girl. The girl's age decided about the legal means which could be used against the violator. The last case is associated with the unlawful acts committed by 
the guards against their wards. The law distinguished situations when such an act was undertaken to the detriment of the girl who was above or under the age of 25 years old.

In conclusion, it must be mentioned that the age of a victim played a significant role in determining the criminal liability of the perpetrator of an unlawful act. That shows that in Roman law the liability of the perpetrator was not determined only by the age of a perpetrator, but also - in some cases - by the age of a victim. For better readability, the summary is also included in the table below.

\section{Tab. 1. Age of a Victim as Crime's Feature}

\begin{tabular}{|c|c|}
\hline $\begin{array}{l}\text { Category } \\
\text { or age limit } \\
\text { of the victim }\end{array}$ & Importance for a perpetrator's liability \\
\hline Childhood & $\begin{array}{l}\text { In the sources of post-classical law (more precisely in the imperial con- } \\
\text { stitutions of the } 4^{\text {th }} \text { century), referring to the Cornelia de sicariis act, which } \\
\text { was directed against assassins, stabbers, poisoners, arsonists and per- } \\
\text { sons committing murder, the ban on the ritual killing of persons in child- } \\
\text { hood was governed. }\end{array}$ \\
\hline $\begin{array}{l}\text { Young man } \\
\text { and young girl } \\
\text { (age of innocence) }\end{array}$ & $\begin{array}{l}\text { In the source material of classical and Justinian law, attention was paid } \\
\text { to the issue of tort (iniuria) committed to the detriment of young boys or } \\
\text { girls in the age described as praetextata aetas, which essentially defined } \\
\text { boys who were below the age when they were allowed to wear a virilis } \\
\text { toga being a symbol of adulthood, and girls who had not yet got married. } \\
\text { In the cases described, persistent walking with such boys or girls was } \\
\text { considered an insult. }\end{array}$ \\
\hline 12 years & $\begin{array}{l}\text { In classical law the limit of } 12 \text { years of age was important for crime known } \\
\text { as stuprum. If that crime were committed to the detriment of a slave, who } \\
\text { was above or below that age, a legal remedy was established, which co- } \\
\text { uld be used by a victim's owner. In the imperial legislation of the } 4^{\text {th }} \text { cen- } \\
\text { tury, there was a reference to the crime of violating the virginity of a girl } \\
\text { under } 12 \text { years of age, by her guardian. In the case where the guardian } \\
\text { committed such an offence to the detriment of a charge below } 12 \text { years } \\
\text { old, he or she was responsible as for the crime of rape. }\end{array}$ \\
\hline $26(25)$ years & $\begin{array}{l}\text { The classical source material contains the information that the guardian } \\
\text { or a curator was held criminally liable under the Iulia de adulteriis coërcen- } \\
\text { dis act, if they married with their ward under the age of } 26 \text { years old, and } \\
\text { was not assigned to be his wife. The use of the numerical limit of } 26 \text { years } \\
\text { of age emphasised that the ban extended until the ward did not complete } \\
\text { the full } 25 \text { years of age. }\end{array}$ \\
\hline
\end{tabular}

Źródło: opracowanie własne. 


\section{Bibliography}

Albertario E., Delictum e crimen nel diritto romano-classico e nella legislazione giustinianea, Milano 1924.

Amielańczyk K., Lex Cornelia de sicariis et veneficis: Ustawa Korneliusza Sulli przeciwko nożownikom i trucicielom 81 r. p.n.e., Lublin 2011.

Amielańczyk K., Rzymskie prawo karne w reskryptach cesarza Hadriana, Lublin 2006.

Amielańczyk K., Teoretyczny model przestęstwa prawa publicznego (crimen publicum) autorstwa Claudiusa Saturninusa (D. 48,19,16) a wspótczesna nauka o przestępstwie karnym, Annales Universitatis Mariae Curie-Skłodowska. Sectio G. Ius 2019, vol. 66, no. 1 .

Amielańczyk K., Vis - pomiędzy prawem rzymskich deliktów prywatnych a rzymskim prawem karnym publicznym, in: Przemoc w świecie starożytnym: źródta, struktura, interpretacje, ed. D. Słapek, I. Łuć, Lublin 2017.

Barden Dowling M., Clemency \& Cruelty in the Roman World, Ann Arbor 2006.

Berger A., Encyclopedic Dictionary of Roman Law, Philadelphia 1953.

Bonini R., D. 48,19,16 (Claudius Saturninus "de poenis paganorum"), Rivista Italiana per le Scienze Giuridiche 1959-1962, series 3, vol. 10.

Cascione C., Roman Delicts and Criminal Law: Theory and Practice, in: Obligations in Roman Law: Past, Present, and Future, ed. Th.A.J. McGinn, Ann Arbor 2012.

Chmiel A., Dzieła naukowe jurystów rzymskich w zakresie prawa karnego, Studia Iuridica Lublinensia 2016, vol. 25, no. 3.

Dolansky F., Togam virilem sumere: Coming of Age in the Roman World, in: Roman Dress and the Fabrics of Roman Culture, ed. J. Edmondson, A. Keith, TorontoBuffalo-London 2008.

Fusco S., Edictum de adtemptata pudicitia [online], Diritto@Storia. Rivista Internazionale di Scienze Giuridiche e Tradizione Romana 2010, no. 9, http:/ / www.dirittoestoria.it /9/ Tradizione-Romana / Fusco - Edictum - adtemptata- pudicitia. htm \#_ftn 80 [access: 13.06.2019].

Guillén Cabañero J., Urbs Roma: Vida y costumbres de los romanos, vol. 1. Vida privada, Salamanca 1988.

Hellwege P., P. Wittig, Delictual and Criminal Liability in Germany, in: Comparing Tort and Crime: Learning from across and within Legal Systems, ed. M. Dyson, Cambridge 2015.

Jońca M., Głośne rzymskie procesy karne, Wrocław 2009.

Kosior W.J., D. 48, 2, 3 i art. 332 k.p.k. - uwagi prawnoporównawcze, Zeszyty Naukowe Uniwersytetu Rzeszowskiego. Seria Prawnicza. Prawo 2018, vol. 22.

Kosior W.J., Kategorie i granice wieku oraz ich znaczenie w prawie rzymskim, Warszawa 2018 (unpublished doctoral thesis, archive of Uniwersytet Humanistycznospołeczny SWPS w Warszawie). 
Kuryłowicz M., Dobromiła Nowicka, Zniesławienie w prawie rzymskim, Wrocław 2013, (Uniwersytet Wroctawski, Prawnicza i Ekonomiczna Biblioteka Cyfrowa, ss. 334) [review], Zeszyty Prawnicze [UKSW] 2014, vol. 14, no. 4.

Kuryłowicz M., Prawo i obyczaje w starożytnym Rzymie, Lublin 1994.

Laes Ch., J. Strubbe, Youth in the Roman Empire. The Young and the Restless Years?, Cambridge 2014.

Lenel O., Das Edictum Perpetuum, Leipzig 1927.

Longo G., Delictum e crimen, Milano 1976.

Lucrezi F., G. Mancini, Crimina e delicta nel tardo antico. Atti del Seminario di Studi. Teramo, 19-20 gennaio 2001, Milano 2003.

Misztal-Konecka J., Bigamia w prawie rzymskim, Lublin 2011.

Mossakowski W., Czyn karalny według koncepcji Klaudiusza Saturnina, Acta Universitatis Wratislaviensis. Prawo 2008, no. 305. Studia Historycznoprawne. Tom poświęcony pamięci Profesora Edwarda Szymoszka.

Nowicka D., Niewerbalne sposoby naruszenia czci w prawie rzymskim, Zeszyty Prawnicze [UKSW] 2016, vol. 16, no. 1.

Nowicka D., Stroje Rzymianek w kontekście brzmienia fragmentu D. 47, 10, 15, 15 (Ulpianus libro 77 ad edictum), Acta Universitatis Wratislaviensis. Prawo 2017, no. 324. Studia Historycznoprawne.

Nowicka D., Zniestawienie w prawie rzymskim, Wrocław 2013.

Oxford Classical Dictionary, ed. S. Hornblower, A. Spawforth, Oxford-New York 2003.

Perry M.J., Gender, Manumission, and the Roman Freedwoman, Cambridge 2014.

Pólay E., Iniuria Types in Roman Law, Budapest 1986.

Robinson O.F., The Criminal Law of Ancient Rome, Baltimore 1995.

Schiller A.A., Trade Secrets and the Roman Law: The Actio Servi Corrupti, Columbia Law Review 1930, vol. 30, no. 6.

Sebesta J.L., Symbolism in the Costume of the Roman Woman, in: The World of Roman Costume, ed. J.L. Sebesta, L. Bonfante, Madison 2001.

Sokala A., Crimen lenocinii: Proces typizacji przestęstwa w prawie rzymskim, Toruńskie Studia Polsko-Włoskie 1994, no. 3.

Stolarek D., Adultera w świetle Lex Iulia de adulteriis coërcendis, Lublin 2012.

Stolarek D., Ustawa julijska o karaniu za cudzołóstwa - 5 tytuł 48 księgi Digestów. Tekst - ttumaczenie - komentarz, Zeszyty Prawnicze [UKSW] 2014, vol. 14, no. 4.

Wiewiorowski J., Regulacja przeciwko naruszeniu praw dziewczyny przez jej opiekuna - obrona wolności wyboru męża czy odrębny typ zbrodni?, U Schyłku Starożytności - Studia Źródłoznawcze 2016, no. 15.

Wittmann R., Die Entwicklungslinien der klassischen Injurienklage, Zeitschrift der Savigny-Stiftung fur Rechtsgeschichte 1974, vol. 91. 


\section{Sum mary}

The conducted research revealed that the matter of age in the sources of Roman law appeared several times in a combination with the victim and was the feature of some delicts and crimes. The article demonstrates that in Roman law, in cases of unlawful acts, not only was the perpetrator's age important, but also sometimes the age of the victim depended on the perpetrator's liability. In modern law, we can also find the provisions in which the perpetrator's liability depends on the age of the victim. For example, Article $200 \S 1$ of the Polish Penal Code can be listed here. The aim of the presented article is to describe unlawful acts (mostly crimes) occurring in Roman law, in which the perpetrator's liability depended on the age of the victim. So far, the above-mentioned thematic hasn't been described in the literature of the subject, because when the matter of age in this context was analyzed, the most attention was focused on the age of the perpetrator and his ability to bear liability. The result of the research was to discover and elaborate Roman law sources where in fact the perpetrator's liability depended on the age of the victim. Selected examples are presented in the text.

Key words: delictual and criminal responsibility, Roman law, age

\section{WIEK POKRZYWDZONEGO JAKO ZNAMIĘ PRZESTĘPSTWA W PRAWIE RZYMSKIM}

\section{Streszczenie}

Przeprowadzone badania ujawniły, że wiek w źródłach prawa rzymskiego, kilkakrotnie pojawił się w połączeniu z osobą pokrzywdzonego (poszkodowanego) i stanowił znamię niektórych deliktów i przestępstw. Pokazuje to, że w prawie rzymskim przy czynach bezprawnych wiek miał znaczenie nie tylko wtedy, gdy dotyczyło to samego sprawcy. Niekiedy odpowiedzialność sprawcy była uzależniona od tego, w jakim wieku był pokrzywdzony. We współczesnym prawie również możemy odkryć przepisy, które odpowiedzialność sprawcy uzależniają od wieku ofiary. Prezentowany artykuł ma na celu przedstawienie czynów bezprawnych występujących w prawie rzymskim, w których odpowiedzialność sprawcy była uzależniona od wieku ofiary. Dotychczas taka tematyka nie była podejmowana $\mathrm{w}$ literaturze przedmiotu, bowiem jeżeli temat wieku $\mathrm{w}$ takim kontekście był analizowany, to najczęściej uwaga skupiała się na wieku sprawcy i jego zdolności do ponoszenia odpowiedzialności.

Słowa kluczowe: odpowiedzialność karna i deliktowa, prawo rzymskie, wiek 


\section{ВОЗРАСТ ПОСТРАДАВШЕГО КАК ПРИЗНАК ПРЕСТУПЛЕНИЯ В РИМСКОМ ПРАВЕ}

\section{Резюме}

Проведенные исследования показали, что возраст в источниках римского права появлялся несколько раз в связи с личностью пострадавшего и являлся отличительной чертой некоторых правонарушений и преступлений. Это показывает, что в римском праве в противоправных деяниях возраст имел значение не только тогда, когда это касалось самого преступника. Иногда ответственность преступника зависела от возраста пострадавшего. В современном праве мы также можем обнаружить законы, которые делают ответственность правонарушителя зависимой от возраста пострадавшего. Цель этой статьи - представить противоправные деяния, имеющие место в римском праве, в которых ответственность исполнителя зависела от возраста пострадавшего. До сих пор такие темы не обсуждались в литературе предмета, поскольку, если тема возраста в этом контексте анализировалась, то чаще всего основное внимание уделялось возрасту преступника и его способности нести ответственность.

Ключевые слова: уголовная и деликтная ответственность, римское право, возраст 
